\title{
ANALYSIS OF THE APPLICATION OF COOPERATION AND IMPROVEMENT OF STORYTELLING SKILLS IN LEARNING ELEMNETARY SCHOOL STUDENTS
}

\section{Dian Sindi Nofianti, Kartika Chrysti Suryandari}

Universitas Sebelas Maret

diansindinofianti96@gmail.com

\section{Article History}

accepted 30/09/2018

approved12/10/2018

published 30/10/2018

\section{Keywords}

cooperation, storytelling skills

\begin{abstract}
The purpose of this study is to describe cooperation and storytelling skills in students in learning. This research is a qualitative descriptive study with observation techniques and questionnaire distribution with sample schools of SD Negeri 5 Panjer Kebumen in 2018/2019 academic year. The results of this study indicate: (1) the application of cooperation in learning causes positive dependence, increases sense of responsibility, facilitates communication, and fosters mutual respect. (2) by improving the ability to tell stories can improve skills in using grammar, accuracy of words and sentences, and fluency in conveying sentences. The conclusion with the application of cooperation in learning can improve storytelling skills.
\end{abstract}

Social, Humanities, and Education Studies (SHEs): Conference Series https://jurnal.uns.ac.id/shes
p-ISSN 2620-9284

e-ISSN 2620-9292 


\section{PENDAHULUAN}

Kerja sama adalah pengelompokan yang terjadi di antara makhluk-makhluk hidup yang kita kenal. Kerja sama atau belajar bersama adalah proses beregu (berkelompok) di mana anggota-anggotanya mendukung dan saling mengandalkan untuk mencapai suatu hasil mufakat,. Ruang kelas suatu tempat yang sangat baik untuk membangun kemampuan kelompok (tim), yang anda butuhkan kemudian di dalam kehidupan Elane B. Johnson (2014:164)

Kerjasama merupakan salah satu bentuk interaksi sosial.Menurut Abdulsyani, kerjasama adalah suatu bentuk proses sosial, dimana didalamnya terdapat aktivitas tertentu yang ditunjukkan untuk mencapai tujuan bersama dengan saling membantu dan saling memahami aktivitas masing-masing.

Kerjasama juga diartikan sebagai kegiatan yang di lakukan secara bersamasama dari berbagai pihak untuk mencapai tujuan bersama (Purwadarminta:1985).Aspek Kerja Sama yaitu : (1)Saling ketergantungan positif. (2)Tanggung jawab perorangan.(3)Komunikasi antar anggota.(4)Saling menghargai.

Bercerita merupakan salah satu kebiasaan masyarakat sejak dahulu sampai sekarang. Pada umumnya manusia senang melakukan kegiatan bercerita dari usia anak sampai dewasa. Bercerita juga dapat dipahami sebagai suatu tuturan yang memaparkan atau menjelaskan bagaimana terjadinya suatu hal, peristiwa, dan kejadian, baik yang dialami sendiri atau orang lain. Kegiatan bercerita termasuk dalam situasi informatif, dengan pengertian dengan bercerita akan membuat pengertianpengertian atau makna-makna yang disampaikan menjadi jelas.

Bercerita merupakan salah satu keterampilan berbicara yang bertujuan untuk memberikan informasi kepada orang lain. Selain itu, dengan bercerita seseorang dapat menyampaikan berbagai macam cerita, ungkapan berbagai perasaan sesuai dengan apa yang dialami, dirasakan, dilihat, dibaca dan ungkapan kemauan serta keinginan membagikan pengalaman yang diperoleh. Kegiatan berbicara khususnya dalam bercerita dapat membangun hubungan mental emosional antara satu individu dengan individu yang lain.

Pelaksanaan kegiatan bercerita harus menguasai bahan/ide cerita, penguasaan bahasa, pemilihan bahasa, keberanian, ketenangan, kesanggupan menyampaikan ide dengan lancar dan teratur sehingga mampu dan terampil dalam bercerita. Keterampilan bercerita tidak hanya diperoleh begitu saja, tetapi harus dipelajari dan dilatih.

Dalam bercerita kita hendaknya memperhatikan aspek-aspek yang harus dipenuhi dalam bercerita yaitu : (1) ketepatan tata bahasa.(2) ketepatan kata dan kalimat, dan (3) kelancaran dalam menyampaikan kalimat.

Pendidikan di abad 21 ini menerapkan 7 ketrampilan dalam pendidikan yaitu (1)berpikir kritis, (2)kreativitas, (3)kerja sama, (4)pemahaman perbedaan budaya, (5)omunikasi, (6)teknologi dan, (7)mengarahkan diri.

Indonesia yang saat ini memasuki generasi platinum dan telah menerapkan 7 ketrampilan pendidikan hendaknya kita sambut dengan bahagia. Hal tersebut juga menjadi kabar baik bagi peneliti karena memberikan peluang besar untuk peneliti melakukan penelitian. Dalam penelitian ini, peneliti tertarik untuk meneliti salah satu aspek ketrampilan pendidikan yaitu kerja sama. Aspek kerja sama dalam pendidikan ini akan dikaitkan dengan ketampilan bercerita siswa. Sehingga peneliti membawa judul penelitian "Analisis penerapan kerja sama dan peningkatan ketrampilan bercerita dalam pembelajaran siswa Sekolah Dasar" 


\section{METODOLOGI}

Metodologi penelitian ini adalah dengan deskriptif kualitatif melalui teknik observasi dan penyebaran angket ya tidak dengan sekolah sampel SD Negeri 5 Panjer siswa kelas II A yang berjumlah 27 siswa tahun 2018/2019.

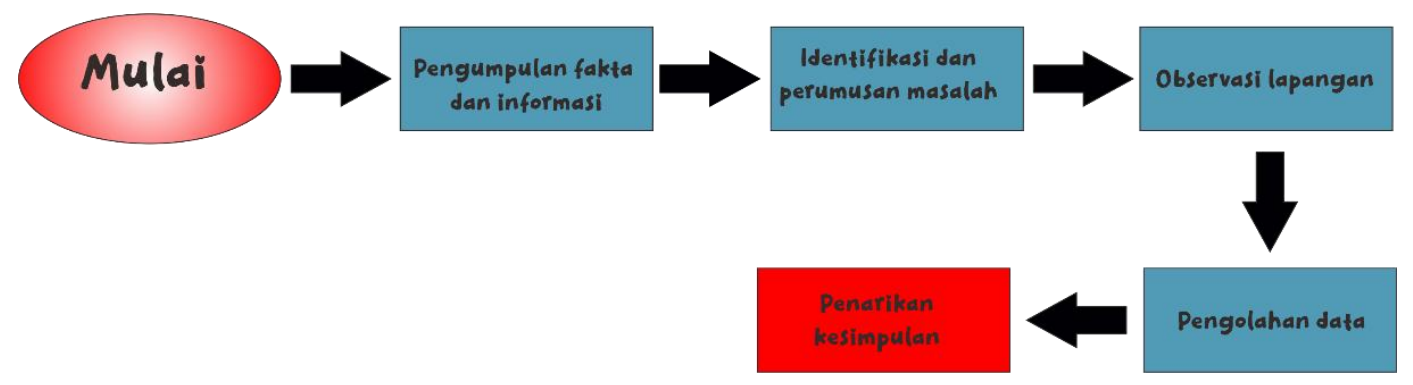

Gb. Alur penelitian

1. Mulai

Pada tahap ini, peneliti yakin untuk melakukan penelitian. Semangat untuk lanjut ke tahap selanjutnya.

2. Pengumpulan fakta dan informasi

Pada tahap ini, peneliti mengumpulkan fatka, data,dan informasi yang aktual untuk di teliti.

3. Identifikasi dan perumusan masalah

Pada tahap ini peneliti mengidentifikasi dan merumuskan masalah menjadi kisikisi penelitian.

4. Observasi lapangan

Pada tahap ini peneliti terjun ke lapangan untuk melalukan penelitiannya.

5. Pengolahan data

Setelah observasi lapangan maka di dapatlah data dan informasi.Kemudian data dan informasi yang di dapat di olah sesuai panduan penelitian dan kisi-kisi penelitian.

6. Penarikan kesimpulan

Pada langkah ini peneliti membuat kesimpulan berdasarkan data yang di peroleh.

\section{HASIL DAN PEMBAHASAN}

\section{a. Kerja sama}

\section{Pengertian kerja sama}

Kerjasama merupakan salah satu bentuk interaksi sosial.Menurut Abdulsyani, kerjasama adalah suatu bentuk proses sosial, dimana didalamnya terdapat aktivitas tertentu yang ditunjukkan untuk mencapai tujuan bersama dengan saling membantu dan saling memahami aktivitas masing-masing.

Kerjasama juga diartikan sebagai kegiatan yang di lakukan secara bersamasama dari berbagai pihak untuk mencapai tujuan bersama (Purwadarminta:1985).

\section{Pelaksanaan kerja sama.}

Ada beberapa cara yang dapat menjadikan kerjasama dapat berjalan dengan baik dan mencapai tujuan yang telah disepakati oleh dua orang atau lebih tersebut yaitu:

1) Saling terbuka, dalam sebuah tatanan kerjasama yang baik harus ada komasi yang komunikatif antara dua orang yang berkerjasama atau unik lebih.

2) Saling mengerti, kerjasama berarti dua orang atau lebih bekerja sama untuk mencapai suatu tujuan, dalam proses tersebut, tentu ada, salah satu yang 
melakukan kesalahan dalam menyelesaikanpermasalahan yang sedang dihadapkan.

Faktor pendukung dan penghambat kerja sama.

Faktor penghambat dalam kerja sama :

- Identifikasi pribadi anggota tim

- Hubungan antar anggota tim

- Identitas tim di dalam organisasi.

Faktor pendukung dalam kerjasama :

Ada 5 strategi dalam pencapaian tujuan dalam kerja sama diantaranya adalah :

- Saling ketergantungan

Saling ketergantungan diperlukan di antara para anggota tim dalam hal ini informasi, sumber daya,pelaksanaan tugas dan dukungan. Adanya ketergantungan dapat memperkuat kebersamaan tim

- Perluasan tugas

Setiap tim harus diberi tantangaaan,karena reaksi atau tanggapan tantangan tersebut akan membantu semangat persatuan, kebanggaan dan kesatuan tim.

Bahasa yang umum

Setiap tim harus menguasai bahasa yang umum dan mudah di mengerti.

- Penjajaran

Anggota tim harus bersedia menyisihkan sikap individualismenya dalam rangka mencapai rangka misi bersama.

- Keterampilan menangani konfrontasi atau konflik

Perbedaan pendapat adalah hal yang wajar. Oleh karna itu dibutuhkan keterampilan dalam penerimaan perbedaan pendapat dan menyampaikan ketidaksetujuan terhadap pendapat orang lain tanpa harus menyakiti orang lain.

\section{Prinsip-prinsip kerja sama.}

- Berorientasi pada tercapainya tujuan yang baik

- Memperhatiakan kepentingan bersama

- Prinsip saling menguntungkan

\section{Aspek Kerja Sama}

1. Saling ketergantungan positif.

2. Tanggung jawab perorangan.

3. Komunikasi antar anggota.

4. Saling menghargai. 


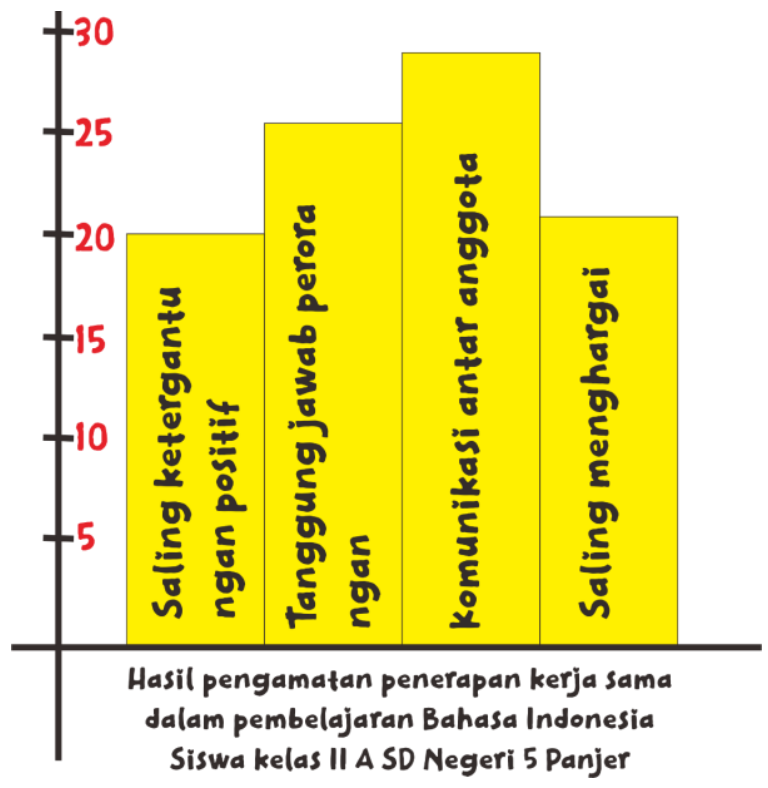

Pada penelitian pelaksanaan kerja sama dalam pembelajaran Bahasa Indonesia di kelas II A SD Negeri 5 Panjer di dapatkan data bahwa penerapan kerja sama dalam pembelajaran membuat siswa menjadi ketergantungan positif. Hal tersebut dikarenakan dari 27 sampel siswa terdapat 20 siswa yang saling ketergantungan positif. Saling ketergantungan positif yang dimaksud disini adalah dalam kerja sama setiap anggota saling membutuhkan dan tidak dapat bekerja sendiri tanpa bantuan dari temannya. Selain itu, kegiatan kerja sama dalam pembelajaran menyebabkan seseorang mempunyai tanggung perorangan. Dalam penelitian ini, dari sampel siswa 27 orang ada 25 siswa yang mempunyai tanggung jawab perorangan yang bagus. Tanggung jawab perorangan yang bagus ini maksudnya, kerja sama dalam pembelajaran membuat siswa paham terhadap tanggung jawabnya terhadap kelompoknya. Kemudian penerapan kerja sama dalam pembelajaran menimbulkan komunikasi baik antar anggota. Dari sampel siswa 27 di hasilkan semua siswa berkomunikasi baik kepada anggotanya. Komunikasi baik yang dimaksud disini adalah komunikasi yang di sampaikan dengan jelas, dapat dipahami oleh lawan bicaranya, dan komunikasi yang yang tidak menimbulkan masalah baru. Dan yang terakhir dalam pembelajaran yang menerapkan kerja sama membuat siswa meningkatkan rasa saling menghargai. Pada penelitian dengan sampel 27 siswa ini ada 22 siswa yang menjujung tinggi rasa saling menghargai dengan baik.

\section{b. Ketrampilan bercerita.}

Bercerita merupakan salah satu kebiasaan masyarakat sejak dahulu sampai sekarang. Pada umumnya manusia senang melakukan kegiatan bercerita dari usia anak sampai dewasa. Bercerita juga dapat dipahami sebagai suatu tuturan yang memaparkan atau menjelaskan bagaimana terjadinya suatu hal, peristiwa, dan kejadian, baik yang dialami sendiri atau orang lain. Kegiatan bercerita termasuk dalam situasi informatif, dengan pengertian dengan bercerita akan membuat pengertianpengertian atau makna-makna yang disampaikan menjadi jelas.

Bercerita merupakan salah satu keterampilan berbicara yang bertujuan untuk memberikan informasi kepada orang lain. Selain itu, dengan bercerita seseorang dapat menyampaikan berbagai macam cerita, ungkapan berbagai perasaan sesuai dengan apa yang dialami, dirasakan, dilihat, dibaca dan ungkapan kemauan serta keinginan membagikan pengalaman yang diperoleh. Kegiatan berbicara khususnya dalam 
bercerita dapat membangun hubungan mental emosional antara satu individu dengan individu yang lain.

Pelaksanaan kegiatan bercerita harus menguasai bahan/ide cerita, penguasaan bahasa, pemilihan bahasa, keberanian, ketenangan, kesanggupan menyampaikan ide dengan lancar dan teratur sehingga mampu dan terampil dalam bercerita. Keterampilan bercerita tidak hanya diperoleh begitu saja, tetapi harus dipelajari dan dilatih.

Dalam bercerita kita hendaknya memperhatikan aspek-aspek yang harus dipenuhi dalam bercerita yaitu : (1) ketepatan tata bahasa.(2) ketepatan kata dan kalimat, dan (3) kelancaran dalam menyampaikan kalimat.

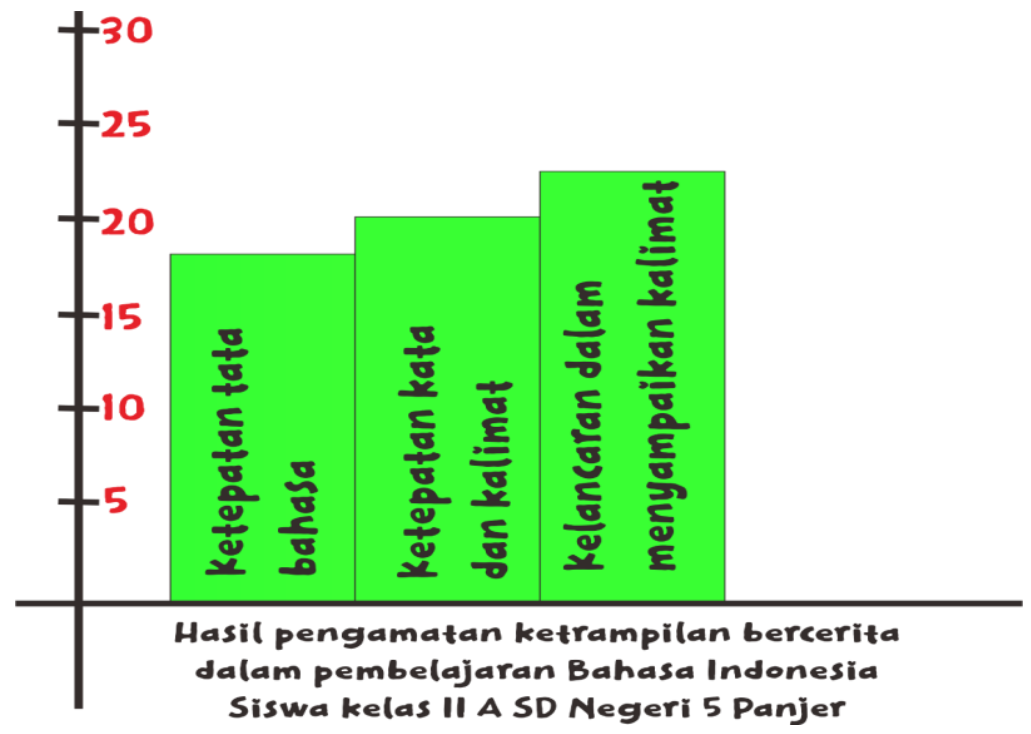

Pada penelitian di SD Negeri 5 Panjer pembelajaran bahasa Indonesia dengan menerapkan ketrampilan bercerita di dapatkan data bahwa dengan sampel siswa 27 ada 19 siswa yang sudah bagus dan tepat tata bahasanya dalam bercerita. Ketepatan tata bahasa yang dimaksud disini adalah dalam bercerita siswa bisa menggunakan tata bahasa yang sesuai. Untuk aspek selanjutnya tentang ketepatan kata dan kalimat dalam penelitian ini dengan sampel siswa 27 terdapat 21 siswa yang sudah bagus dan sesuai dalam pemilihan kata dan kalimat ketika bercerita. Aspek yang selanjutnya adalah kelancaran dalam menyampaikan kalimat, siswa SD Negeri 5 Panjer kelas II A dalam bercerita lancar dalam menyampaikan kalimat. Dari sampel 27 siswa ada 24 siswa yang sudah lancar dalam menyampaikan kalimat ceritanya.

\section{SIMPULAN}

Pendidikan di abad 21 ini menerapkan 7 ketrampilan dalam pendidikan yaitu (1)berpikir kritis, (2)kreativitas, (3)kerja sama, (4)pemahaman perbedaan budaya, (5)omunikasi, (6)teknologi dan, (7)mengarahkan diri.

Dalam penelitian ini, peneliti fokus kepada satu ketrampilan pendidikan yaitu kerja sama. Yang kemudian dihubungkan dengan ketrampilan bercerita. Dan menghasilkan kesimpulan bahwa dalam pembelajaran yang menerapkan kerja sama memberikan pengaruh positif bagi siswa yaitu membuat siswa saling ketergantungan positif, menimbulkan rasa tanggung jawab perorangan, meningkatkan komunikasi antar anggota, dan membuat siswa mengedepankan rasa saling menghargai satu sama lain. 
Ketrampilan kerja sama yang dihubungkan dengan ketrampilan bercerita memberikan pengaruh positif yaitu siswa dalam bercerita dapat memilih tata bahasa dengan tepat, pemilihan kata dan kalimat dalam bercerita sesuai. Dan dalam menyampaikan cerita, kalimat yang disampaikan lancar.

Maka dari penelitian ini memberikan kabar baik untuk pembelajaran siswa sekolah dasar untuk bisa menggunakan ketrampilan kerja sama dalam pembelajaran karena ketrampilan kerja sama ini dapat dihubungkan dengan aspek ketrampilan lainnya seperti ketrampilan bercerita. Yang pada akhirnya memberikan pengaruh positif bagi siswa-siswi sekolah dasar.

\section{DAFTAR PUSTAKA}

Abdulsyani. (1994). Sosiologi Skematika, Teori, dan Terapan. Jakarta: Bumi Aksara.

Johnson, Elaine B. (2014). Contextual Teaching and Learning: Menjadikan Kegiatan

Belajar Mengajar Mengasyikan dan Bermakna. Bandung: Kaifa.

Purwadarminta. (1985). Kamus Umum Bahasa Indonesia. Jakarta: Balai Pustaka 